\title{
'Pay Your Tax!' How tax avoidance became a prominent issue in the public sphere in the UK
}

Jen Birks, Nottingham University, and John Downey, Loughborough University

\section{Introduction}

While Habermas' original model of the public sphere has attracted enormous attention from across the humanities and social sciences in the English-speaking world since its belated translation over twenty-five years ago, his subsequent modifications to the model are much less well-known. This is a pity because these modifications provide a much more sophisticated understanding of the complex and dynamic operation of the public sphere that can help scholars explain how changes occur in public discourse and beyond.

In this chapter we will examine, as a case study that informs public sphere theory-building, the work of UK Uncut, a resource-poor anti-austerity group formed in 2010 that campaigns energetically on the issue of tax avoidance by corporations and wealthy individuals in the UK. It has succeeded in intervening in the public sphere to the extent that tax avoidance is now a major issue in mainstream media news and comment, and one that political elites seek to address in policy-making and ultimately contain. This is a remarkable transformation since the issue had been pursued by traditional civil society organisations without much purchase for some years, including a significant investigation by The Guardian, which conceded that tax avoidance was a 'MEGO' issue - my eyes glaze over - and difficult to get the public exercised about. We argue that this rise to prominence is not simply down to the actions of UK Uncut, but arises because of the coincidence of a complex recipe of causal conditions. On the way, we will offer a method to analyse the public sphere in flux (analytical process tracing) and we will theorise this process, which may be of help to other scholars in their attempts to understand how, when and why protest can permeate mainstream public sphere institutions, influence public discourse, and affect policy.

\section{The Public Sphere in Flux}

While Habermas' original formulation of his public sphere thesis is widely known, his more recent and much more sophisticated account of the nature of publicness has attracted comparatively little attention (1989, 1996, 2006). In his original formulation, Habermas charts 
the rise and fall of the public sphere. In the post Second World War period he sees a 'refeudalisation' of the public sphere. Here economic and political elites have captured or colonized the public realm and essentially engage in a dance in front of citizens aimed ultimately at winning votes in periodic elections. Habermas' more recent work, in contrast, modifies this theory of elite capture that led in his earlier work to a problematic account of the public sphere in stasis. What impressed Habermas was the ability of new social movements - feminism and the green movement in the 1970s and the 1980s - to make an impact on public debate that ultimately led to some degree of economic, social and political change. These were initially voices from the margins that, subject to modification, became mainstream. Habermas' revisions in this area are influenced greatly by the work of Bernhard Peters and the notion of a 'sluice-gate' public sphere. Peters argues that the control of elites over public discourse is far from complete: "the centre controls the direction and dynamics of these processes only to a limited degree. Changes can start just as much at the periphery as at the centre" (1993: 340). This presents encouragement to social movements and resource-poor marginal or peripheral groups generally and a certain amount of succour to elites as they can present themselves as legitimate representatives of citizens and as responsive to society.

Peters' model is made up of a number of concentric circles. On the periphery we have resource-poor groups. Moving towards the centre we have mass media institutions such as newspapers and broadcasting followed by courts and legislatures with the executive forming the core. Ideas flow toward the centre through the operation of sluice-gates; communication pressure builds up between these different levels at times of crisis, passing through once the pressure has reached a certain point. In previous work we have elaborated upon this model, tracing the process of discursive and political change from the periphery to the centre of the public sphere with respect to the national DNA database in the UK (Downey et al., 2012). We sought to trace the process of discursive and social change through specifying the various ingredients in the causal recipe that led to such change. The ingredients were made up of the presence of 'carriers' or actors in civil society who develop narratives that resonate with broader publics at times of crisis that are then picked up and modified by media and political elites. Here we wish to build on such a causal recipe but also introduce a more sophisticated account of the mobility of ideas between different parts of the public sphere (see Downey, 2014 for an elaboration of this argument) and the relationship between elites and peripheral publics.

The model of communication flowing from the periphery to the centre via sluice-gates is too linear and it underestimates elite capture. Ideas flow both ways. Peripheral groups pick up, 
for example, ideas expressed by mass media institutions. They modify and dramatise them. Then in advantageous circumstances (a crisis of one type or another) these ideas flow back into more powerful institutions of the public sphere as elites become more receptive to new ideas. Elites in turn engage in a process of modification and containment and these ideas are then disseminated back through the concentric circles of the public sphere. The ability of elites to contain the discursive impulses from peripheral publics depends not only on the ideas themselves (how radical they are) but also on their ability to refashion the discourse and come up with publicly credible responses. It depends also and crucially on the depth and duration of the crisis. What we are proposing therefore is a complex model of discursive change in the public sphere that examines multidirectional mobility of ideas in a public sphere in flux.

\section{Methodology}

There are special difficulties in devising methods that can capture mobility of ideas across the public sphere and no clear methodological tool-kit has been developed to do this. Media research methods often entail fixing, isolation and abstraction. Methods of media textual analysis (content, frame and discourse analysis, for example) will give a 'snapshot' of what a particular sample of media content was at a particular time and place. If we are interested in temporal change, then we need a number of snapshots in the manner of time-lapse photography. That will give us, however, only a sense of whether ideas migrate from one place to another over time but these methods still fix and isolate a moving target and it provides no explanation of why ideas might move around - the economic, political and ideological forces that determine relative mobility. Consequently, it is necessary to employ methods that not only fix content but also methods that can capture process.

Process-tracing is a case study small-n method developed and in relatively widespread use in political science and in sociology. It has been influential in historicizing the study of social science. The basic aim of process-tracing is to discover the causal process, chain, mechanism, conditions that explain the transition from one state of affairs to another. It is particularly useful in cases where there are multiple interacting variables or causal conditions. While process-tracing may have helped to historicize the social sciences it does not yet appear to have encouraged a consideration of process embedded in space as well as time but there is no logical reason why this could not be the case. George and Bennett (2005) outline a number of types of process-tracing ranging from the detailed but atheoretical historical narrative to narratives aimed at producing more general forms of explanation at a 
higher level of abstraction. The type of process-tracing that particularly interests us is somewhere between the two - the 'analytic explanation' variety - which converts

\begin{abstract}
A historical narrative into an analytical causal explanation couched in explicit theoretical forms. The extent to which a historical narrative is transformed into a theoretical explanation can vary. The explanation may be deliberately selective, focusing on what are thought to be particularly important parts of an adequate or parsimonious explanation (George and Bennett, 2005: 211)
\end{abstract}

If we think of the public sphere as a number of concentric circles with the executive at the centre, surrounded first by legislature and judiciary, then by powerful media institutions, and ultimately by resource poor groups at the periphery, process-tracing seeks to track the movement of ideas from one arena to the other via sluice-gates. This involves taking snapshots of the state of play of these ideas in the various arenas at different points in time (in this case through media content analysis) and then paying attention to the carriers of these ideas and the discursive and political opportunity structures that enabled these ideas to be articulated and to take hold. A striking aspect of the tax avoidance issue is 'multidirectionality' or 'non-linearity' in that it was only through the work of relatively mainstream organisations that those at the margins had something to dramatise and ultimately have an effect on the legislature and the executive in the UK.

\title{
4. A Very Brief History of Tax Avoidance Campaigning in the UK
}

It is useful to identify a series of articles written by Nick Davies for the Guardian in 2002 as the starting point of sustained attention and investigation by a national newspaper into the issue. Nick Davies' two special reports published in July 2002 explored the Inland Revenue's strategy of accommodation and appeasement towards tax avoidance practices of multinational corporations and the situation of wealthy 'non-doms' (those resident but not domiciled in the UK) paying little or no tax on their non-UK income and wealth in the UK and the supposed battle between Chancellor Gordon Brown and the Treasury over this with Brown wishing to tax this group with the Treasury resisting attempts to do so.

Already established at this point in time is the 'capital and human flight' argument that if the UK government attempts to tax wealthy individuals or corporations that they would simply move their operations overseas adversely affecting the UK economy. The Guardian offers other explanations for previous governments' inaction, including non-doms' donations to the 
Conservative Party (though the Lakshmi Mittal scandal had already established that Labour were not immune to this). A lack of leadership, resources and skilled inspectors meant that banks, accountancy firms, and tax lawyers advising multinational corporations kept ahead of the state, resulting in a loss to the Treasury of $£ 25 b n$ per annum (24/07/02 p11). By October, however, Davies noted that non-doms were beating off government interest in their wealth $(14 / 10 / 02$ p14) and public interest in the story waned.

The next significant encounter with the issue on the part of the Guardian was their reporting of the Tax Justice Network's establishment of an office in London, a year after it was founded (Duncan Campbell, 21/09/04 p21). Here, however, the focus was not on the cost of tax avoidance to the UK Treasury but rather on how multinationals were avoiding taxes on profits earned in developing economies, due to founder John Christensen's work with Oxfam on the issue. The Tax Justice Network was again cited the following week, by George Monbiot, in support of his criticism of Gordon Brown's inaction on the issue (28/09/04 p21), but the issue failed to gain momentum.

Guardian articles over the following two years included criticisms of the legal but highly dubious moral practices of accountancy firms that help firms to avoid taxes (Prem Sikka, Professor of Accounting at Essex University, 05/09/05 p15), the UK's 'cash in hand' culture (Richard Adams, 12/8/06 p.25), and praise for the Institute for Fiscal Studies review into the UK's tax system, which bemoaned the explosion of the tax avoidance business (Polly Toynbee, 15/09/06 p35). In 2007 coinciding with Gordon Brown becoming Prime Minister there was a relative flurry of articles about tax avoidance hoping (forlornly as it proved) that his ascendancy would now mean that the Labour government would pursue tax avoiders with more vigour, including one in which John Christensen argued once again that the time has come to confront the tax-haven monster' (30/05/07 p28).

In 2008 the Guardian returned energetically to the story with a report erroneously claiming that Tesco used offshore companies to avoid paying corporation tax on property sales in the UK, whereas, it transpired, they had been avoiding stamp duty (though Private Eye subsequently alleged that they were avoiding corporation tax after all). Tesco issued a libel writ, along with three other actions globally. Guardian editor Alan Rusbridger commented at the time, "To use the law of criminal libel - which they are using in one of the other actions seems to me incredibly menacing and seems to be done with the purpose of inhibiting criticism" (Press Gazette 2008). 
Undeterred, in February 2009 the Guardian launched an investigation, The Tax Gap, examining the tax affairs of more than 20 companies on the front pages of the newspaper over two weeks. Investigations editor David Leigh led a team of seven journalists dedicated to the task, including Richard Brooks from Private Eye. It drew repeatedly on the TUC's recently published Touchstone pamphlet The Missing Billions: The UK Tax Gap (2008) by Richard Murphy, estimating the cost of tax to the UK Treasury at £25bn per annum. Rusbridger told the Culture, Media and Sport Select Committee in May that year that prepublication legal work on the investigation had cost $£ 90,000$, and that legal costs were deterring investigative journalism.

Despite receiving support from Liberal Democrat MPs, including the Deputy Leader, Vince Cable, who contributed an article arguing that the crisis should be an occasion to confront tax-avoiders (03/02/09 p26), and Matthew Oakeshott, who used parliamentary privilege to undermine the high court injunction Barclays obtained against the Guardian in relation to documents obtained by a whistleblower ${ }^{1}$, and despite the financial crisis, public concern of tax avoidance remained low. Truly tax avoidance had proved to be a MEGO issue.

Over the course of almost a decade, then, the Guardian newspaper together with a number of pressure groups (Tax Justice Network) and non-governmental organisations (Oxfam, Action Aid) had campaigned against tax avoidance by both wealthy individuals and corporations. These campaigns, however, failed to ignite public anger or to persuade the government to make a step-change in its efforts to collect tax. Why was this the case? Reasons for this can be divided into three areas: an unpromising ideological environment; an unhelpful political environment; and an infertile economic environment.

Ideologically, the Guardian and pressure groups were battling against the prevailing neoliberal ideology that regarded increased government action to collect tax owed as either antibusiness (and thus harming the interests of UK PIc) or as resulting in endless bureaucratic red-tape. Politically, calls for greater action on the part of the Labour government were seen as being potentially divisive and it was easy to categorise tax campaigners as being 'old Labour', with associated fears for the party of being characterised as anti-business, and as under the thumb of the unions. Divisions within the labour movement, therefore, tended to act as a break on the development of political momentum behind the campaign. It was left to the Liberal Democrats to seize tax avoidance as a political issue prior to the 2010 General Election campaign. Economically, the UK was experiencing a period of growth, however illusory that turned out to be. Whilst the public finances were in good shape, the estimated

\footnotetext{
${ }^{1}$ The writ obliged them to remove documents detailing the bank's involvement in tax avoidance provided by a whistleblower from their website and preventing them from publicising their availability elsewhere on the internet
} 
$£ 25 \mathrm{bn}$ per annum tax gap did not appear to matter! With the onset of the financial crisis, collecting more tax from corporations was seen to be inopportune and public expenditure was being boosted to stave off economic collapse. By late 2010, however, all of these conditions had changed.

\section{Evidence that tax issue became present in mass media public sphere}

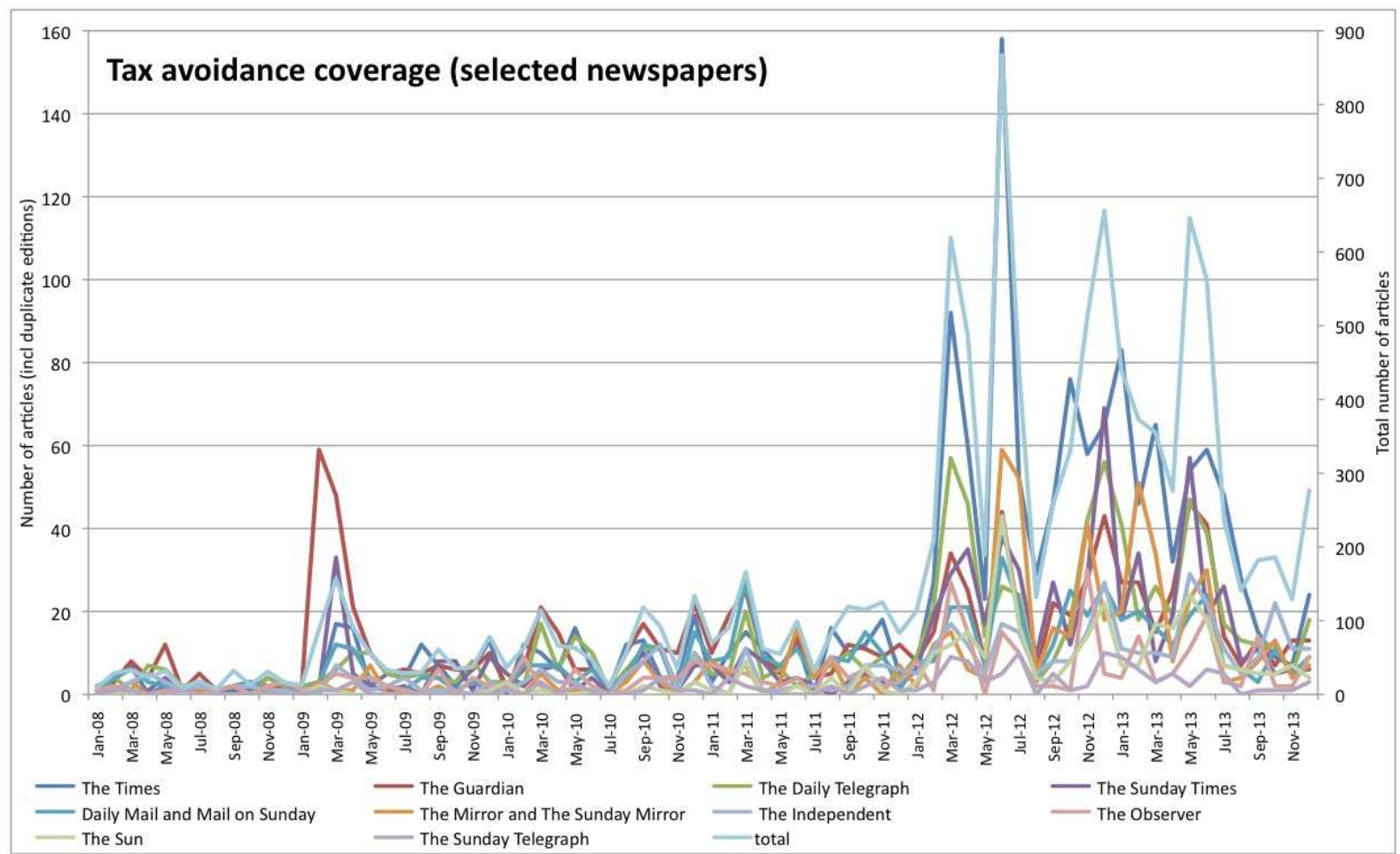

While as a consequence of the Guardian campaign in early 2009 there was a spike in national newspaper coverage of tax avoidance, this was fleeting. It was not until September 2010 that we can see the gates of the sluice slowly rising. That month saw widespread coverage of the HMRC's deal with Vodafone, in which they reportedly negotiated their tax bill down by £6bn. This story was broken by Richard Brooks in Private Eye, and as he says, its particular significance was that it "coincided with the Tories announcing their programme of spending cuts", and that "UK Uncut was formed as a direct result" in October 2010 (interview, 
October 2014). Making use of social media, UKUncut dramatised the issue of tax avoidance by holding protests outside and within high street stores that were associated with tax avoidance. Their message was not new, having been firmly established by Richard Murphy's work for the TUC; as Murphy says, "they had a ready-made narrative, in a sense, and l'd written a lot of that narrative, and they picked it up and ran with it. And they ran with it very successfully. Sitting outside Vodafone, and saying 'pay your tax' got headlines" (interview, August 2014). UK Uncut effectively amplified the alternative narrative to austerity where others had failed.

In the seven months prior to September 2010 there were 377 articles that mentioned tax avoidance in 12 UK national newspapers. This was during a General Election period where tax avoidance was part of the Liberal Democrats' Manifesto and where there were revelations of Lord Ashcroft's non-dom status (the largest and most prominent Conservative Party donor). In the seven months from September 2010 the issue was mentioned in 627 articles. UK Uncut were mentioned explictly by national newspapers for the first time in November 2010 but in the following 5 months were were mentioned 364 times. To give some indication of comparative visbility, the TUC and the Tax Justice Network had been mentioned in relation to tax avoidance in national newspapers 136 and 139 times respectively from 2007 to 2010 .

It was then subsequently picked up by political elites. Margaret Hodge, for example, the Chair of the Public Accounts Committee of the House of Commons was mentioned only 3 times in relation to tax avoidance in 2010 but in 2012 and 2013 was mentioned a total of 834 times. As the issue was picked up by political elites mentions of UK Uncut fell. They played a part in the initial opening of the sluice gates but as the water starts running through the issue is picked up by established resource-rich elites who then attempt to steer the issue according to their own interests.

Having provided evidence of the sluige-gates opening, we will now discuss the complex coincidence of causes that caused this discursive shift.

\section{Resonant Narratives: Pay your Tax!}

The anti-austerity protest agenda needed to create a powerful alternative narrative to challenge the established narrative that cuts were regretfully necessary. The government's sleight of hand in shifting the financial crisis caused by bad mortgage debt traded by banks to a fiscal crisis of public debt was and is successful, an example perhaps of how neoliberal 
policymakers capitalise on crisis, diagnosing the cure for the ills of neoliberal capitalism with a purer version, with lower corporate taxes and a smaller state. UK Uncut saw this as "a matter or rhetoric, and we had to challenge that rhetoric, and we did that by talking about tax" (Jo, UK Uncut, interview November 2014). They presented austerity as 'ideological', and proposed a crackdown on tax avoidance as an alternative to cuts, much as the TUC had two years earlier, but also succeeded in dramatising and popularising the argument. The particular significance of this is that they managed, at least initially, to avoid the trap between the spectacular but typically delegitimized and the socially legitimised but typically disregarded (Juris 2011). As Jo says, "we didn't want to be portrayed as a marginal group, the thing we were really keen to avoid was the sense that there are political activists and there is the rest of the public and there's something dividing them." They achieved this both by anticipating the delegitimsing news frames routinised in protest reporting, and reproducing and repurposing legitimising news frames.

The emergence of UK Uncut through a Twitter hashtag forms an important part of their legitimating narrative, as is evident on the 'about UK Uncut' section of the group's website ${ }^{2}$.

At that point [the initial Vodafone shop protest], UK Uncut only existed as \#ukuncut, a hashtag someone had dreamed up the night before the protest. As we sat in the doorway, chanting and handing leaflets to passers by, the hashtag began to trend around the UK and people began to talk about replicating our action. The idea was going viral. The seething anger about the cuts had found an outlet. Just three days later and close to thirty Vodafone stores had been closed around the country. (UK Uncut n.d.)

This emphasises the spontaneity of their origins, as something that grew without direction from above - avoiding the accusation of being instrumentalised by vested interest (which, for much news media, would include trade unions) - and its basis in an emotional pre-political response, as an anger that pre-existed and was already seeking an 'outlet'.

Because the organisers saw the need and the potential to build a critical mass, they took what Rucht (2013) calls an 'adaptation' orientation to mainstream media, drawing on members' experience of working with the media in NGOs and previous activism to appeal to dominant news values. A filmmaker known to organisers through environmental activist networks responded to the call out for that first action and produced a film that, hand-held camera aside, uses the visual language of broadcast news, including sped-up video, filler

\footnotetext{
${ }^{2}$ http://www.ukuncut.org.uk/about/ukuncut
} 
shots focusing in on store-front signage, and on-the-street vox pops. The video was broadcast on Newsnight, one of the BBC's flagship news programmes, in January 2011, and members of UK Uncut appeared on the programme several times over 2011.

Both voice-over and activist interviewees use similar frames: a straightforward connection between tax avoidance and public sector cuts and the solution as similarly uncomplicated. The connection is simply made through the juxtaposition of clauses, or their temporal or sequential connection: "the government's allowing corporations like Vodafone to get away with not paying taxes then cutting our public services", "at the same time he's making these huge cuts to welfare". The policy alternative to public spending cuts is presented as equally obvious: "a simple one is just getting everyone in society to pay their fair share and that means the corporations stop dodging tax and pay what they owe". It is notable that they talk of 'fairness' rather than 'social justice' or 'equality', appealing to news media frames of 'fairness to taxpayers' more typically associated with stories initiated by the Taxpayers Alliance and against public sector pay disputes (Birks 2014).

The moral justifications are left for bystanders to make in vox pops, in an interesting reversal of the established role of the bystander in news reporting of protest, whereby they stand in for public disapproval of the protesters. Here is it used to demonstrate public disapproval of corporate tax avoidance among a demographically diverse selection of individuals - not only an angry denunciation of 'fat cats', but also a nice elderly lady agreeing that 'it is all wrong', and two young men, typically assumed to be disengaged from politics. Two of the contributors object that ordinary people owning small sums to HMRC are pursued aggressively with additional charges, so it cannot be fair that Vodafone should be allowed to negotiate their debt down. In a way, this is the common sense reversal of the false analogy that the government make between the public finances and balancing the family budget.

\section{Receptive Media and Political Elites}

The personal authenticity of protesters' outrage was surprisingly broadly recognised, not just in the Guardian and Observer, but also the Times, Sunday Times, Daily Mail and People. In some cases this took the form of vague assertions of the public mood, describing big business as the "focus of rising anger", "growing disquiet" (Observer 05/12/10, p20), and "legitimate public anger" (David Wighton, Times 15/12/10, p23). However, the diversity of protesters was also frequently noted, and more often than not in direct reference to spontaneous viral spread of the movement through social media, suggesting that UK Uncut's self-legitimising narrative was directly picked up, simultaneously a testament to dominant understandings of 'social media'. 
The epidemic of students and grandmothers lying on pavements to bar access to global brands is just the latest example of the way in which Twitter and other social media websites are being used to mobilise loose coalitions of ordinary but angry citizens. (Independent 18/12/10, p8)

Similarly, Times commentator Stefanie Marsh $(18 / 12 / 10, \mathrm{p} 8)$ defined them as both a "grassroots organisation" and "without doubt the most successful example of "viral activism" in the country", referring to supporters as "followers" and "fans" in social media terms. Jo from UK Uncut argues that there was an aspect of novelty as "for a while we were one of the pioneers of using social media to organise politically", but also that journalists are "obsessed with social media" partly as an easy source, but also as a perceived threat to the profession.

One of the quotes from elderly protesters demonstrates an awareness of dominant media framing, and even of their own legitimating role: "And don't let anyone say this protest is hijacked by anarchists. If anything, it's hijacked by pensioners!" (Observer 05/12/10, p20). Echoing UK Uncut's video, the Guardian described bystanders as "fairly sympathetic" (04/12/10), whilst Polly Toynbee (Guardian 07/12/10, p29) went as far as to say that "many were supportive and a few joined in"3. The porous boundary between protesters and bystanders undermines the typical definition of the public in contradistinction to protesters, but also problematised their treatment. Both the Sunday Mirror and Sunday Times $(05 / 12 / 10)$ reported aggressive removal of protesters by Top Shop security guards, including one who said she was a shopper. Even the Sunday Express quoted a protester describing how security guards carried out by her ankles and hair and describing the experience as "quite scary" (05/12/14, p12).

There was some evidence of traditional delegitimisation, but initially it was limited to a smattering of references to disruption and inconvenienced shoppers. It was only after the second student anti-tuition fee protest march, when a branch of Top Shop plastered with UK Uncut signs had its window broken and Prince Charles's car was jostled nearby that the Telegraph was able to characterise UK Uncut as a violent mob of anti-capitalists and anarchists (Telegraph blog 10/12/10, Daily Telegraph 11/12/10). The Mirror (10/12/10), too, described "panic-stricken and angry" shoppers barricaded (by security) inside a branch of Top Shop due to a UK Uncut protest (although the panic seems to have been caused by the impression that it was a bomb scare).

\footnotetext{
${ }^{3}$ Jo reports that Polly Toynbee quietly joined several UK Uncut actions in London and was very supportive
} 
Interestingly, the corporate perspective was rather muted, but primarily because the companies implicated decided on a strategy of silence, presumably to avoid adding fuel to a fire that they hoped would die out quickly. Whilst Arcadia told The Sunday Times (05/12/10) that the protests were "highly irresponsible" as their demands would only "stop business, stop employment", and claiming their own social responsibility on the basis of being "one of the largest employers in the country", they declined to comment to the Mail on Sunday, or The People (05/12/10). Other than a widely reported terse dismissal that the £6bn tax bill was an "urban myth" (a soundbite also, interestingly, attributed to HMRC) Vodafone made no comment. Vodafone's head of communications explained to The Independent (17/12/10, Business p34) that the company has "decided against a direct confrontation with the protesters" because "getting into a debate with protesters would be counter-productive". Newspaper commentators and business editors similarly muted their prior assertion of business interests as being identical to national interest. The capital flight argument appeared in Tracey Corrigan's business column in the Daily Telegraph on $19^{\text {th }}$ November, but by $8^{\text {th }}$ December she conceded "Business needs to win the popularity contest; Protests against tax-dodging may be misguided, but they have caught the public mood". David Prosser in The Independent's business pages (11/12/10, p54) similarly admits that there is "much to admire about the campaign group UKuncut", objecting only that government is the appropriate target for protest, rather than businesses, who are not going to pay more than they have to. Prosser also draws a moral equivalence between corporate schemes and tax arrangements available to married couples in a piece representing "the business view" alongside "the protesters' view" from a UK Uncut member pointing out, among other things, that the distinction is marked by the spirit rather than the letter of the law $(18 / 12 / 10, p 8)$. Even incoming CBI president Roger Carr is quoted making a distinction between "efficient" tax planning and "artificial" arrangements (Observer 12/12/10, Business p43). Polly Toynbee (Guardian 07/12/10, p29) suggests that it was the material presence of Arcadia shops and Cadbury factories in Britain that made it clear that they were clearly based in and making its profit in Britain (in comparison with a "flighty finance company"), drawing on a common sense notion of fairness, but also hinted at a more populist angle, which was picked up by the Daily Mail.

It was moves by Kraft, the Swiss firm that had controversially acquired Cadbury's, to make the brand a subsidiary and thereby reduce its UK tax liabilities that attracted the attention of Daily Mail City Editor, Alex Brummer (06/12/10). He introduced a nationalistic tone with an article headlined "THIS PLUNDER OF OUR HERITAGE". Lamenting the way that "the Government has stood by while huge chunks of Britain [...] have been sold to foreign buyers", the article was peppered with reference to the nation, including "hard-working, tax- 
paying Britons", "the British brand", "Britain's industrial base", and "the nation's tax revenues". Brummer acknowledges the neo-liberal argument that the "financial sacrifice" was made to attract inward investment, "But when the economy collapsed and manufacturing output fell by 10 per cent, these foreign owners' cynical and deliberately planned tax avoidance strategies left Britain's corporate tax base horribly exposed". The distinction between the interests of corporations and citizens (or 'taxpayers', in the paper's more clientalistic terms) is transferred into an 'us and them' discourse about Britons and foreigners, to better suit the editorial ideology of the newspaper.

The first evidence of a political response was as early as Monday $6^{\text {th }}$ December, when Treasury minister, David Gauke announced plans to close loopholes in corporate tax law, and to consult on further proposals. Both the Guardian (13/12/10 leader column, p28; 07/12/10 Polly Toynbee, p29, Alex Hawkes 07/12/10, p23) and Independent (06/12/10, Business p34) concluded that UK Uncut were instrumental in forcing, amplifying or accelerating governmental action on tax avoidance. However, Hawkes quotes a UK Uncut spokesman remarking that "it was "great to see the process works so quickly", but that this would prevent a fraction of total annual tax avoidance.

More significantly, however, Margaret Hodge was prompted to ask questions of HMRC at hearings of the Public Accounts Committees, which Richard Brooks credited as "essentially the big political change" (interview, October 2014), and Richard Murphy credited for placing the issue on the agenda at the 2013 G8 summit at Lough Earne, for the introduction of an anti-avoidance principle and ultimately for a drop in tax avoidance (interview, August 2014).

"UK Uncut exists within a kind of ecosystem of other activist groups and people doing work, and the fact that there were already people out there who had done all this fantastic research on tax, and it kind of laid the groundwork. It meant that we, direct action and activists, we were the kind of wedge, we helped to open this space up, and it was great that there were people there that were ready to fill that space who could talk about it. And we never pretended to be experts, we never tried to be, and it's so good that there were people out there who were doing that. And what I think is happening now with the tax issue is that other people are now pushing it forward in a way in which a group like UK Uncut never could." (Jo, UK Uncut, interview November 2014) 


\section{Conclusion}

At first sight, the case of the rise to prominence of tax avoidance in the UK's public sphere is an example of Peters' sluice-gates in operation. The actions of a group at the margins resulted in a discursive shift in mainstream media and in how the core institutions of the public sphere sought to deal with the issue. We have added two modifications to the sluicegate model: first, we see this discursive and policy shift as the product of a complex causal recipe where the actions of UK Uncut were a necessary but not sufficient cause; second, we argue that discursive shifts need to be understood not as linear processes but as multidirectional. Without the prior work of mainstream public sphere actors such as Oxfam, the TUC, the Guardian to establish the evidence and arguments, UK Uncut would have had nothing to dramatise. This points not only to the continued importance of investigative journalism, which is under threat in UK broadcast and print journalism, but also casts doubt on the idea that marginal actors can bring about change unaided. Key to understanding this is process-tracing over time and space: tracking the migration of ideas from the mainstream to the margins and then back again in a different set of circumstances that affect both political and discursive opportunity structures.

\section{References}

Birks, Jen (2014) News and Civil Society. Farnham: Ashgate

Downey, John, Mike Stephens and Jan Flaherty (2012) 'The 'sluice-gate' public sphere and the national DNA database in the UK' in Media Culture Society 34(4): 439-456

Downey, John (2014) 'Flux and the Public Sphere' in Media Culture Society 36(3): 367-379

George, Alexander L. and Andrew Bennett (2004) Case Studies and Theory Development in the Social Sciences. Cambridge, MA: MIT Press

Habermas, Jürgen (1989) The Structural Transformation of the Public Sphere. Cambridge, MA: MIT Press

Habermas, Jürgen (1996) Between Fact and Norms. Cambridge: Polity / Blackwell 
Habermas, Jürgen (2006) 'Political Communication in Media Society: Does Democracy Still Enjoy an Epistemic Dimension? The Impact of Normative Theory on Empirical Research' Communication Theory 16 411-426

Juris, Jeffrey S. (2011) 'Mediating and Embodying Transnational Protest: Internal and External Effects of Mass Media Global Effects of Mass Global Justice Actions' in Simon Cottle and Libby Lester (eds.) Transnational Protest and the Media. Oxford: Peter Lang, pp98-108

Peters, Berhard (1993) Die Integration moderner Gesellschaften., Frankfurt am Main:

Suhrkamp

Press Gazette (2008) 'Tesco Out to Gag Me With a £1.6m Action’ in Press Gazette, 25 April 2008. Available from: http://www.pressgazette.co.uk/node/40949

Rucht, Dieter (2013) 'Protest Movements and Their Media Usages' in Bart Cammaerts, Alice Mattomni and Patrick McCurdy (eds.) Mediation and Protest Movements. Bristol / Chicago: Intellect

TUC (2008) The Missing Billions: The UK Tax Gap. Touchstone Pamphlets. Available from: www.tuc.org.uk/sites/default/files/documents/completedownload.pdf 